Utah State University

DigitalCommons@USU

1970

\title{
Selective Breeding of Honeybees for Alfalfa Pollen Collection: With Tests in High and Low Alfalfa Pollen Collection Regions
}

William P. Nye

Utah State University

O. Mackensen

Follow this and additional works at: https://digitalcommons.usu.edu/piru_pubs

Part of the Entomology Commons

\section{Recommended Citation}

Nye, W. P., and O. Mackensen. 1970. Selective Breeding of Honeybees for Alfalfa Pollen Collection: With Tests in High and Low Alfalfa Pollen Collection Regions. J. Apic. Res. 9(2):61-64, tables.

This Article is brought to you for free and open access by the Pollinating Insects Research Unit at DigitalCommons@USU. It has been accepted for inclusion in All PIRU Publications by an authorized administrator of DigitalCommons@USU. For more information, please contact digitalcommons@usu.edu.

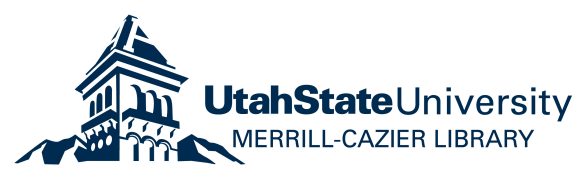


Journal of Apicultural Research 9(2): 61-64 (1970)

\title{
SELECTIVE BREEDING OF HONEYBEES FOR ALFALFA POLLEN COLLECTION: WITH TESTS IN HIGH AND LOW ALfalfa pollen COLLECTION REGIONS*
}

\author{
William P. Nye and Otto Mackensen \\ Entomology Research Division, Agricultural Research Service, U.S.D.A. Logan, \\ Utah 84321 \& Baton Rouge, Louisiana 70803, U.S.A.
}

Manuscript received for publication 7th January 1970

\section{Summary}

Four groups of honeybees were tested for their tendency to collect alfalfa pollen in south-western Idaho (where honeybees do not normally collect alfalfa pollen) and in northern Utah (where they do). In the seventh generation of the line with a strong tendency to collect alfalfa pollen (high line), the percentage of pollen collectors returning to the hive with alfalfa pollen was $35 \cdot 6 \%$ in Idaho and $87 \cdot 4 \%$ in Utah; the average percentage in the line with a low tendency to collect alfalfa pollen (low line) was $9.9 \%$ in Idaho and $36.4 \%$ in Utah. The percentages of alfalfa pollen collectors in the two mating groups of line B (an unrelated strain) occupied an intermediate position, at 15.7 and $17.7 \%$ respectively in Idaho and 77.0 and $64.1 \%$ in Utah.

In Idaho, the high line possessed the highest mean number of alfalfa pollen collectors per sample (15); line B (average for both groups) had an intermediate number (9); and the low line the lowest (4). In Utah, the three corresponding groups of colonies occupied the same positions in relation to the mean number of alfalfa pollen collectors per sample, but there was much less difference between them (respectively, 18,14 and 13). The yield of honey was greatest from the line B colonies, which were the least inbred.

\section{Introduction}

In six generations of selective breeding of honeybees (Apis mellifera) foraging on alfalfa, we have succeeded in developing one line that has a high proportion of alfalfa pollen collectors (APC) and one line that has a low proportion. When the sixth generation of these bees was tested in $1967,86 \%$ of the pollen-collecting bees in the high APC line and $8 \%$ in the low APC line were collectors of alfalfa pollen. During these tests, we concluded from the results of hybridization and backcrosses that the characteristic of collecting alfalfa pollen is dependent on many genes that have additive effects (Nye \& Mackensen, 1965, 1968; Mackensen \& Nye, 1966, 1969). However, all the testing had been done in northern Utah where honeybees normally collect considerable quantities of pollen from alfalfa. There are other areas in the United States where honeybees are known to collect very little or none. For example, Bohart (1957) reported that honeybees collect pollen from alfalfa quite freely in Oklahoma, Arizona and southern California, but only in intermediate amounts in Kansas, Utah and Nebraska, and rarely in the north and north-west. Also, Norman Waters (personal communication) reported that honeybees did not collect pollen from alfalfa in the area of Idaho Agricultural Experiment Station (Parma, Idaho), and that only an occasional alfalfa flower is tripped by nectar collectors. The reasons for the differences are not clear, but they probably involve a combination of the effect of climate on the plants, the

\footnotetext{
* In co-operation with Utah and Louisiana Agricultural Experiment Stations
} 
volume of nectar secreted, the concentration of sugar, and the nature and abundance of competing sources of pollen. In the present paper the alfalfa pollen-collecting performances of four strains of honeybees in 1968 are compared at a poor collecting site (Parma, south-western Idaho) and at a favourable site (Howell, northern Utah).

\section{Methods}

The seventh generation of the high and low APC lines and the second generation of line B (started from a commercial strain first tested in 1967) were used.

Our breeding and testing methods were the same as those for the sixth generation (Mackensen \& Nye, 1969). In all, 15 colonies of each of the high and low APC lines and 26 colonies of each of two mating groups of line B were tested. All matings were done by instrumental insemination, and matings in line $B$ were individual to increase variability and to permit gamete selection; the others were multiple-drone matings with $8 \mu$ l of semen.

The queens were introduced to the test colonies between 9th and 17th May 1968. Then 12 colonies of the high and of the low APC lines and 17 colonies of each of the two mating groups of line $B$ were moved to an alfalfa seed field at Parma. The remaining colonies were placed on an alfalfa seed field at Howell, as in previous years.

At Parma, between 3rd and 25th July, the returning field bees were sampled about twice a week until 5 samples had been taken from each colony (bees were sucked with a vacuum device into a cyanide jar or cloth bag). At Howell, between 16th July and 5th August, the field bees were sampled in the same manner about twice a week until 8 samples had been taken from each colony. The samples from both locations were killed, refrigerated, and later the bees were classified as foragers with or without pollen; the pollen collectors were then sorted according to the floral sources of the pollen they carried. In this paper, we present only the number of foragers returning without pollen, the total number of pollen collectors, the number of collectors of alfalfa pollen, the percentage of pollen collectors that were collectors of alfalfa pollen, and the yield of honey.

Except for the yield of honey, the data collected at Parma were examined statistically by analysis of variance, and the percentages were converted to arc sine (as given by Bliss, 1937). The data collected at Howell were not analysed statistically because of the small number of colonies located there.

Nearly all alfalfa grown for seed in the Parma area was irrigated before the bloom stage and as needed thereafter to maintain blossoming and plant attractiveness to insect pollinators. The stands were thicker than is recommended, and some parts of the field were too dry and some were too wet.

\section{Results and Discussion}

The average performance of the colonies at Parma, where other pollens were plentiful, and at Howell where other pollens were scarce, is given in Table 1. The analysis of variance of the data collected at Parma showed a highly significant difference between the groups for almost all classes of data analysed and also between data taken on different dates (Table 2). The exceptions were: (1) there was a significant interaction $(\mathbf{P}<0.05)$ between groups and sampling dates for foragers without pollen and also for alfalfa pollen collectors, although any interaction was not significant for pollen collectors as a whole; (2) there was no significant difference between data for alfalfa pollen collectors on different sampling dates. 
TABLE 1. Results obtained from tests on four groups of colonies at two locations in 1968.

\begin{tabular}{|c|c|c|c|c|c|c|}
\hline Test group & $\begin{array}{l}\text { No. } \\
\text { colonies }\end{array}$ & $\begin{array}{c}\text { Mean no. } \\
\text { foragers } \\
\text { without } \\
\text { pollen }\end{array}$ & $\begin{array}{l}\text { Mean no. } \\
\text { pollen } \\
\text { collectors }\end{array}$ & $\begin{array}{c}\text { Mean no. } \\
\text { alfalfa } \\
\text { pollen collectors }\end{array}$ & $\begin{array}{l}\% \text { alfalfa } \\
\text { pollen } \\
\text { collectors }\end{array}$ & $\begin{array}{c}\text { Honey yield } \\
\text { per colony } \\
(\mathrm{kg})\end{array}$ \\
\hline \multicolumn{7}{|c|}{ Parma, Idaho } \\
\hline High APC line & 12 & $78 \mathrm{~B}$ & $41 \mathrm{~B}$ & $15 \mathrm{~A}$ & $36 \mathrm{~A}$ & 77 \\
\hline Low APC line & 12 & $87 \mathrm{~A}$ & $39 \mathrm{~B}$ & $4 \mathrm{C}$ & $10 \mathrm{C}$ & 99 \\
\hline Line $B_{1}$ & 17 & $71 \mathrm{C}$ & $57 \mathrm{~A}$ & $8 \mathrm{~B}$ & $16 \mathrm{~B}$ & 177 \\
\hline Line $B_{2}$ & 17 & $78 \mathrm{~B}$ & $58 \mathrm{~A}$ & $10 \mathrm{~B}$ & $18 \mathrm{~B}$ & 253 \\
\hline \multicolumn{7}{|c|}{ Howell, Utah } \\
\hline High APC line & 8 & 113 & 20 & 18 & 87 & 55 \\
\hline Low APC line & 2 & 134 & 36 & 13 & 36 & 88 \\
\hline Line $B_{1}$ & 8 & 131 & 24 & 18 & 77 & 110 \\
\hline Line $B_{2}$ & 7 & 131 & 17 & 9 & 54 & 110 \\
\hline
\end{tabular}

Means followed by different letters are significantly different $(P<0.01)$

Comparisons were also made between the variances for the four groups of colonies at Parma (Table 2). The low APC colonies had the highest number of foragers returning without pollen. The line $\mathrm{B}$ colonies had the greatest total number of pollen collectors (though in the two mating groups of line B only 15.7 and $17.7 \%$, respectively, collected alfalfa pollen), and they had an intermediate number of alfalfa pollen collectors. The high APC line had a low total number of pollen collectors, but it had the highest number $(P<0.01)$ of alfalfa pollen collectors and did well at Parma, indicating effective selection of the high line for alfalfa pollen collection. The low line did as well as at Howell in earlier years.

TABLE 2. Statistical comparisons of differences shown in Table 1 (groups at Parma only).

\begin{tabular}{lcccc}
\hline & $\begin{array}{c}\text { Foragers } \\
\text { without } \\
\text { pollen }\end{array}$ & $\begin{array}{c}\text { Total } \\
\text { pollen } \\
\text { collectors }\end{array}$ & $\begin{array}{c}\text { Alfalfa } \\
\text { pollen } \\
\text { collectors }\end{array}$ & $\begin{array}{c}\text { Arc sine } \\
\text { for alfalfa } \\
\text { pollen collectors }\end{array}$ \\
\hline High APC vs. low APC & $* *$ & n.s. & $* *$ & $* *$ \\
High APC vs. line B & $*$ & $* *$ & $* *$ & $* *$ \\
High APC vs. line B & n.s. & $* *$ & $* *$ & $*$ \\
Line B B $_{1}$ vs. low APC & $* *$ & $* *$ & $* *$ & $*$ \\
Line B $\mathrm{B}_{1}$ vs. line B & n.s. & n.s. & n.s. & n.s. \\
Line $\mathrm{B}_{2}$ vs. low APC & $* *$ & $* *$ & $* *$ & $*$ \\
\hline
\end{tabular}

** $\quad \mathrm{P}<0.01$

* $\quad \mathrm{P}<0.05$

n.s. no significant difference

Data taken on different dates were likely to have been affected by the following:

1. pesticides: DDT, toxaphene and parathion drifted on to the field at Parma on 3 rd, 12th-15th, 18th and 24th July, killing all foraging honeybees, leafcutter bees and alkali bees;

2. the time of day at which samples were taken; 
3. the growing season, which is rather longer at Parma than at Howell;

4. cultural practices in the area;

5. plant competition: alfalfa was highly attractive to all insect visitors searching for nectar and pollen, but when sweet corn pollen became available on 17th July it attracted an average of $52 \%$ of all honeybee pollen collectors.

Honey yields were estimated from the number of supers removed (Table 1) and were not proportional to the numbers of presumed nectar collectors (foragers returning without pollen), as in the 1967 tests. However, colonies of line B produced the most honey, and it is possible that this resulted from their being the least inbred.

Of the colonies placed at Howell, where other pollens were scarce, the high APC line collected an average of $87.4 \%$ of its pollen from alfalfa, which was about the same as that collected in the two previous generations; the low APC line collected $36.4 \%$, which is very much more than in the two previous generations; and the two groups of line B colonies occupied an intermediate position, $77.0 \%$ and $54 \cdot 1 \%$.

Although the percentage of alfalfa pollen collectors was lower at Parma than at Howell, it was greater than expected, in view of the reported lack of collection in the area. It may, therefore, have been an unusually favourable season for alfalfa pollen collectors at Parma. However, the general relationship between the lines with reference to alfalfa pollen collection was about the same in the two locations.

The selection of a seventh generation in the high and low APC lines produced little change in the percentage of alfalfa pollen collectors over the fifth and sixth generations, which strengthens our conclusion (Mackensen \& Nye, 1969) that a plateau has been reached in both lines and that further selection may not result in any improvement.

Line B will be useful in crosses with our high APC line to restore vigour; alternatively it may be used to produce a hybrid, by mating queens of line B to drones of the high APC line, to obtain colonies with only slightly inbred queens and vigorous hybrid workers.

\section{Acknowledgements}

We wish to acknowledge the assistance of Dr. N. D. Waters in locating the alfalfa field for placement of the honeybee colonies, and Bill Stewart for providing the alfalfa field and the location for the bees at Parma; also Earl Wood for the bee locations in his alfalfa field, and the assistance of DeLar Cheney in collecting the data at Howell.

\section{References}

BLiss, C. I. (1937) The analysis of field experimental data expressed as percentages. Plant Protection Bul., Leningrad No. 12

Bohart, G. E. (1957) Pollination of alfalfa and red clover. Annu. Rev. Ent. $2: 355-380$

MACKENSEN, O. \& NYE, W. P. (1966) Selecting and breeding honeybees for collecting alfalfa pollen. J. apic. Res. 5(2) : 79-86

(1969) Selective breeding of honeybees for alfalfa pollen collection: sixth generation and outcrosses. J. apic. Res. 8(1) :9-12

NyE, W. P. \& MACKeNSEN, O. (1965) Preliminary report on selection and breeding of honeybees for alfalfa pollen collection. J. apic. Res. 4(1) : 43-48

(1968) Selective breeding of honeybees for alfalfa pollen: fifth generation and backcrosses. J. apic. Res. $7(1): 21-27$ 